\title{
FROM THE DESK OF EDITOR in CHIEF
}

(J Bangladesh Coll Phys Surg 2019; 37: 104)

DOI: https://doi.org/10.3329/jbcps.v37i2.40570

Shuvo Nabo Barsho. Wishing all the fellows of BCPS, a new year rich with the blessings of love, joy and laughter. Hope you will be in good health, happiness, and success in this year and always.

I have tried my best to publish the journal of BCPS regularly in time. Members of the editorial board and distinguished reviewers helped me all the time to meet the deadline of publication. I thank all of them from the core of my heart for their dedicated and continuous endeavor to maintain the quality of the journal.
The editorial board is now prepared to apply for indexing of the journal to PUBMED. I hope Allah will fulfill our goal.

Lastly I thank president and honorary secretary general of BCPS for their continuous support and inspiration to improve the quality of the journal.

\section{Prof. Ferdousi Islam}

Editor-in-Chief 